\title{
PENGARUH PEMBERIAN JERAMI PADI DENGAN BERBAGAI PERLAKUAN (FISIK, KIMIA, BIOLOGI DAN KOMBINASI) TERHADAP KARKAS DOMBA (Ovis aries) JANTAN LOKAL
}

\section{(Effect of Treatment with Rice Straw (Physical, Chemical, Biological and Combined) to Carcass Local Rams (Ovis aries))}

\author{
Junaedi Gultom $^{1}$, Edhy Mirwandhono ${ }^{2}$ dan Hasnudi ${ }^{2}$ \\ 1 Mahasiswa Program Studi Peternakan Fakultas Pertanian Universitas Sumatera Utara \\ 2 Staf Pengajar Program Studi Peternakan Fakultas Pertanian Universitas Sumatera Utara
}

\begin{abstract}
Rice straw is an agricultural waste in Indonesia that can be used as animal feed. This study aimed to determine the effect of rice straw with various treatments (physical, chemical, biological and combinations) against the percentage of carcasses, slaughter weight and fat percentage of the local rams. The experiment was conducted at the Laboratory Animal Sciences Program Faculty of Agriculture, Animal Husbandry University of North Sumatra for 4 (four) months starting from March to June 2012. This research method using 20 rams with an average initial body weight range $11.16 \pm 0.98 \mathrm{~kg}$ and 3month age range. The research method used was a completely randomized design (CRD) consisting of 4 treatments and 5 replications. The treatments used were P1 (rice straw processed physically (chopper) + concentrate), P2 (rice straw treated with the chemical $(\mathrm{NaOH})+$ concentrate), P3 (straw treated with biological (Aspergillus niger) + concentrate) and $\mathrm{P} 4$ (rice straw + concentrates processed in combination). The results showed that administration of rice straw in carcass weight parameter obtained results are significantly different $\mathrm{P}>0.05$. Carcass percentage, fatty heart, kidney fat and the pelvic fat were not significantly different $\mathrm{P}>0.05$ level. Carcass weight, carcass percentage, fat percentage heart and kidney fat was highest in P3 treatment, whereas carcass weight and carcass lowest percentage contained in the P2 treatment. The conclusion of this study is the presence of rice straw with various treatments (physical, chemical, biological and combined) in sheep feed is still a positive influence where the provision of rice straw with various treatments do not reduce the weight of the ram carcass.
\end{abstract}

Keywords: Ram, rice straw, the percentage of carcasses, fat.

\begin{abstract}
ABSTRAK
Jerami padi merupakan limbah pertanian yang terbesar di Indonesia yang dapat dimanfaatkan sebagai pakan ternak. Penelitian ini bertujuan untuk mengetahui pengaruh pemberian jerami padi dengan berbagai perlakuan (fisik, kimia, biologi dan kombinasi) terhadap persentase karkas, bobot potong dan persentase lemak terhadap domba lokal jantan. Penelitian dilaksanakan di Laboratorium Biologi Ternak Program Studi Peternakan Fakultas Pertanian Universitas Sumatera Utara selama 4 (empat) bulan dimulai bulan Maret sampai Juni 2012. Metode penelitian ini menggunakan 20 ekor domba jantan dengan rataan bobot badan awal berkisar $11.16 \pm 0.98 \mathrm{~kg}$ dan umur berkisar 3 bulanan. Metode penelitian yang digunakan adalah rancangan acak lengkap (RAL) yang terdiri dari 4 perlakuan dan 5 ulangan. Perlakuan yang digunakan adalah P1 (Jerami padi yang diolah secara fisik (chopper) + konsentrat), P2 (Jerami padi yang diolah dengan kimia $(\mathrm{NaOH})+$ konsentrat), P3 (Jerami yang diolah dengan biologis (Aspergillus niger) + konsentrat) dan P4 (Jerami padi yang diolah secara kombinasi + konsentrat). Hasil penelitian menunjukkan bahwa pemberian jerami padi pada parameter bobot karkas diperoleh hasil yang berbeda nyata $\mathrm{P}<0.05$. Persentase karkas, lemak jantung, lemak ginjal dan lemak pelvis tidak berbeda nyata $\mathrm{P}>0.05$. Bobot karkas, persentase karkas, persentase lemak jantung dan lemak ginjal tertinggi terdapat pada perlakuan P3, sedangkan bobot karkas dan persentase karkas yang terendah terdapat pada perlakuan P2. Kesimpulan penelitian ini adalah keberadaan jerami padi dengan berbagai perlakuan (fisik, kimia, biologi dan kombinasi) pada pakan domba masih memberikan pengaruh positif dimana dengan pemberian jerami padi dengan berbagai perlakuan tidak menurunkan bobot dari karkas domba tersebut.
\end{abstract}

Kata kunci : Domba jantan, jerami padi, persentase karkas, lemak. 


\section{PENDAHULUAN}

Perkembangan usaha domba potong di tanah air saat ini masih dikelola dengan cara tradisional. Peternakan domba memiliki potensi yang besar seiring dengan meningkatnya kebutuhan manusia akan kebutuhan protein hewani untuk peningkatan gizi. Daging domba merupakan salah satu daging yang memiliki kandungan gizi yang tinggi dan rasa yang enak. Oleh karena itu permintaan akan daging ini semakin lama semakin meningkat terutama pada hari-hari besar.

Dalam usaha peningkatan produksi domba, saat ini telah diupayakan dalam manajemen pemeliharaan yang intensif. Diantaranya adalah dengan penggunaan hijauan yang berkualitas baik yang terdiri dari rumput dan legium serta penggunaan pakan tambahan (konsentrat) yang memilki nilai gizi yang tinggi sehingga bisa mencukupi kebutuhan ternak akan zat nutrisi. Saat ini, pakan tambahan yang biasa dipakai peternak dirasa cukup mahal. Sedangkan hijauan yang tersedia saat ini hanya memiliki kandungan protein yang rendah dan tingginya kadar serat kasar yang merupakan masalah utama. Untuk mengatasi hal tersebut, maka perlu dicari sumber pakan alternatif untuk mengganti pakan utama sebagai pelengakap tambahan yang mempunyai potensi baik dari segi kualitas maupun kuantitas.

Jerami padi merupakan limbah pertanian terbesar di indonesia. Produksi per hektar sawah bisa mencapai 12 - 15 ton bahan kering setiap panen, tergantung lokasi dan varietas tanaman. Sejauh ini, pemanfaatan jerami padi sebagai pakan ternak baru mencapai $31-39 \%$, sedangkan yang dibakar atau dimanfaatkan sebagai pupuk $36-62$ $\%$, dan sekitar 7 - $16 \%$ digunakan untuk keperluan industri (BPS, 2004). Jerami padi merupakan salah satu pakan alternatif yang paling banyak dipakai untuk memenuhi kekurangan hijauan pakan ternak. Jerami padi merupakan limbah pertanian yang bernutrisi lebih baik dibanding dengan limbah pertanian yang lain, serta mudah diperoleh untuk dimanfaatkan sebagai pakan ternak. Namun bahan pakan tersebut berkualitas rendah karena rendahnya kandungan nutrien dan kurang dapat dicerna. Jerami padi tidak banyak dimakan ternak, biasanya ditumpuk dan dibiarkan mengering. Kalaupun diberikan pada ternak hanya sedikit yang dimakan karena tingkat palatabilitas jerami yang rendah.

Kendala utama dari pemanfaatan jerami padi sebagai bahan pakan ternak adalah kandungan serat kasar yang tinggi dan protein kasar serta kecernaan yang rendah. 
Jerami itu sendiri untuk pakan ternak sebetulnya kualitasnya sangat rendah, sehingga harus di olah terlebih dahulu agar kualitasnya meningkat. Kandungan gizi jerami padi yang berupa protein hanya 3-5 \%, padahal rumput, misalnya rumput gajah mencapai 1214\%. Demikian pula kadar vitamin dan mineralnya juga sangat rendah, sehingga jerami padi dikategorikan pakan yang "miskin gizi”. Disamping itu serat jerami sangat liat atau dengan kata lain kecernaannya rendah, hanya sekitar 25-45\%, tergantung varietasnya (BPS, 2002).

Penggunaan jerami secara langsung atau sebagai pakan tunggal tidak dapat memenuhi kebutuhan nutrisi ternak. Dengan pengolahan, daya cerna jerami padi dapat ditingkatkan hingga $70 \%$ dan kandungan protein dapat mencapai 5 - $8 \%$ (BPS, 2004). Menurut data Badan Pusat Statistik Sumatera Utara produksi padi tahun 2010 luas areal sawah di Sumatera Utara mencapai 702.308 hektar sedangkan jumlah jerami yang dihasilkan 7,5 ton per hektar (Arafah, 2005) dengan perbandingan jerami dan gabah yang dihasilkan 3:2. Dengan luas areal sawah 702.308 hektar maka akan menghasilkan jerami sebanyak 5.267.310 ton/ha/tahun.Bahwa pakan yang baik merupakan semua bahan yang bisa diberikan pada ternak dan mempunyai zat gizi yang baik.(Parakkasi,1995).

Pakan yang diberikan sebaiknya jangan sekedar untuk mengatasi rasa lapar atau sebagai pengisi perut saja melainkan harus benar - benar bermanfaat untuk kebutuhan hidup,membentuk sel sel baru dan menganti sel sel yang rusak dan untuk produksi (Widayati dan Widalestari,1996)

Pemanfaatan jerami padi dipergunakan sebagai pakan untuk ternak ruminansia dengan mengolah jerami padi tersebut dengan pengolahan secara fisik/ mekanik, kimia, dan biologis menjadi pakan yang lebih bermutu sehingga di dalam pengolahannya dapat bermanfaat untuk meningkatkan bobot badan dan memenuhi kebutuhan gizi ternak ruminansia. Berdasarkan uraian diatas penulis ingin meneliti pengaruh pemberian jerami padi dengan berbagai perlakuan (fisik, kimia, biologi, kombinasi) terhadap persentase karkas, bobot potong dan persentase lemak terhadap domba lokal jantan. 


\section{BAHAN DAN METODE}

\section{Lokasi dan Waktu Penelitian}

Penelitian dilaksanakan di Laboratorium Biologi Ternak Program Studi Peternakan Fakultas Pertanian Universitas Sumatera Utara. Berlangsung selama 4 bulan mulai bulan Maret sampai Juni 2012.

\section{Bahan dan Alat Penelitian}

Objek penelitian berupa 20 ekor domba jantan dengan berat berkisar $11.16 \pm$ $0.98 \mathrm{~kg}$ dan rata-rata umur domba tersebut berkisar 3 bulanan. Ransum yang digunakan berbentuk pakan konsentrat yang terdiri dari bungkil inti sawit, dedak padi, molases, pod kakao, urea, mineral dan garam. Jerami padi sebagai pengganti pakan rumput ternak. Urea sebagai bahan amoniasi jerami padi dan penyusun konsentrat, Aspergilus niger sebagai mikroorganisme (fermentor) untuk fermentasi jerami padi, $\mathrm{NaOH}$ untuk pengolahan jerami padi secara kimiawi, obat-obatan seperti obat cacing (kalbazen), anti bloat untuk obat kembung, Rhodallon untuk desinfektan dan vitamin. Air minum diberikan secara ad libitium.

Alat yang digunakan antara lain: kandang individual 20 unit dengan ukuran $1 \mathrm{x}$ 0,5 m beserta perlengkapannya, tempat pakan dan minum, timbangan untuk menimbang bobot hidup berkapasitas $50 \mathrm{~kg}$ dengan kepekaan $2 \mathrm{~kg}$, timbangan berkapasitas $2 \mathrm{~kg}$ dengan kepekaan $10 \mathrm{~g}$ untuk menimbang pakan, chopper digunakan untuk menchopper bahan pakan, grinder digunakan untuk menghaluskan bahan pakan, thermometer digunakan untuk mengetahui suhu di dalam dan diluar kandang, alat pembersih kandang, alat penerangan kandang. Alat tulis untuk mencatat data selama penelitian.

\section{Metode Penelitian}

Rancangan percobaan yang digunakan dalam penelitian ini adalah rancangan acak lengkap (RAL) dengan 4 perlakuan dan 5 ulangan. Adapun perlakuan tersebut sebagai berikut:

$\mathrm{P}_{1}=$ Jerami padi yang diolah secara fisik (chopper) + Konsentrat

$\mathrm{P}_{2}=$ Jerami padi yang diolah dengan kimia $(\mathrm{NaOH})+$ Konsentrat

$\mathrm{P}_{3}=$ Jerami yang diolah dengan biologis (Aspergilus niger) + Konsentrat

$\mathrm{P}_{4}=$ Jerami padi yang diolah secara kombinasi (kimia dengan biologi + konsentrat) 
Tabel 1. Kandungan Nutrisi Jerami Padi

\begin{tabular}{clcc}
\hline No & \multicolumn{1}{c}{ Bahan } & PK $(\%)$ & SK $(\%)$ \\
\hline 1 & Jerami padi yang diolah secara fisik & 4,35 & 28,08 \\
2 & Jerami padi yang diolah secara kimia & 4,50 & 26,15 \\
3 & Jerami padi yang diolah secara biologi & 6,03 & 24,14 \\
4 & Jerami padi yang diolah secara kombinasi & 5,59 & 23,16 \\
\hline
\end{tabular}

Tabel 2. Kandungan nutrisi konsentrat yang digunakan selama penelitian

\begin{tabular}{clccccc}
\hline No & \multicolumn{1}{c}{ Bahan } & Bahan $(\%)$ & PK(\%) & SK $(\%)$ & LK(\%) & TDN(\%) \\
\hline 1 & Kulit Buah Kakao & 13 & 0.96 & 4.30 & 0.18 & 6.39 \\
2 & Bungkil Inti Sawit & 20 & 3.08 & 3.38 & 0.48 & 16.2 \\
3 & Dedak Padi & 18 & 2.48 & 2.02 & 1.48 & 11.57 \\
4 & Onggok & 27 & 0.43 & 2.81 & 0.11 & 20.52 \\
5 & Tepung daun singkong & 13 & 3.25 & 1.56 & 0.91 & 11.77 \\
6 & Molasses & 5 & 0.2 & 0.02 & 0.0 & 4.05 \\
7 & Garam & 1 & 0 & 0 & 0 & 0 \\
8 & Mineral & 1 & 0 & 0 & 0 & 0 \\
9 & Urea & 2 & 5.60 & 0 & 0 & 0 \\
\hline & Total & 100 & 16 & 14.09 & 3.16 & 70.5 \\
\hline
\end{tabular}

\section{Peubah Penelitian}

\section{Bobot Karkas (kg)}

Bobot tubuh ternak setelah dipuasakan dikurangi dari berat kepala, darah, organorgan internal, kaki (carpus dan tarsus) ke bawah dan kulit.

\section{Persentase Karkas (\%)}

Bobot karkas segar dibagi dengan bobot tubuh kosong dikali seratus persen. bobot tubuh kosong adalah bobot potong dikurangi isi saluran pencernaan.

\section{Persentase Lemak (\%)}

a) Perrsentase lemak ginjal (\%)

Diperoleh dari perbandingan bobot lemak ginjal dengan bobot karkas dikali $100 \%$.

b) Persentase lemak jantung Diperoleh dari lemak yang menyelubungi jantung dibagi dengan bobot karkas dikali $100 \%$

c) Perrsentase lemak pelvis (\%)

Diperoleh dari perbandingan bobot lemak pelvis dengan bobot karkas dikali $100 \%$. 


\section{HASIL DAN PEMBAHASAN}

Adapun hasil rekapitulasi penelitian dapat dilihat pada Tabel 3.

Tabel 3. Rekapitulasi hasil penelitian

\begin{tabular}{lcccc}
\hline \multirow{2}{*}{\multicolumn{1}{c}{ Parameter }} & \multicolumn{4}{c}{ Perlakuan } \\
\cline { 2 - 5 } & P1 & P2 & P3 & P4 \\
\hline Bobot karkas (kg) & $3,97^{\mathrm{ab}} \pm 0,14$ & $3,65^{\mathrm{a}} \pm 0,07$ & $3,99^{\mathrm{b}} \pm 0,02$ & $3,66^{\mathrm{ab}} \pm 0,05$ \\
Persentase karkas (\%) & $31,93^{\mathrm{tn}} \pm 0,40$ & $31,74^{\mathrm{tn}} \pm 0,98$ & $32,63^{\mathrm{tn}} \pm 1,13$ & $32,38^{\mathrm{tn}} \pm 0,07$ \\
Persentase lemak jantung (\%) & $2,25^{\mathrm{tn}} \pm 0,07$ & $2,30^{\mathrm{tn}} \pm 0,14$ & $2,25^{\mathrm{tn}} \pm 0,07$ & $2,25^{\mathrm{tn}} \pm 0,07$ \\
Persentase lemak ginjal (\%) & $2,15^{\mathrm{tn}} \pm 0,07$ & $2,40^{\mathrm{tn}} \pm 0,14$ & $2,45^{\mathrm{tn}} \pm 0,21$ & $2,30^{\mathrm{tn}} \pm 0,00$ \\
Persentase lemak pelvis (\%) & $2,20^{\mathrm{tn}} \pm 0,14$ & $2,10^{\mathrm{tn}} \pm 0,00$ & $2,10^{\mathrm{tn}} \pm 0,14$ & $2,15^{\mathrm{tn}} \pm 0,00$ \\
\hline Ket: pemberian notasi yang sama pada tiap parameter menunjukkan perlakuan memberikan pengaruh \\
\multicolumn{4}{l}{ yang tidak berbeda nyata $(\mathrm{P}>0,05)}$.
\end{tabular}

\section{Bobot Karkas}

Bobot karkas tertinggi terdapat pada perlakuan P3 (jerami padi yang diolah secara fisik biologi(Aspergillus niger) ditambahkan konsentrat) yaitu sebesar 3,99 dan rataan bobot karkas terendah terdapat pada P2 (jerami padi yang diolah dengan kimia $(\mathrm{NaOH})$ ditambahkan dengan konsentrat) yaitu sebesar 3,65.Produksi bobot karkas dari setiap perlakuan menunjukkan hasil yang berbeda (pada Tabel 3). Peneliti berasumsi bahwa hal ini dipengaruhi oleh bobot hidup domba, bobot hidup domba dipengaruhi oleh kandungan nutrisi dan komposisi pakan yang dikonsumsi oleh domba. Hal ini sesuai dengan pernyataan Davendra (1977), yang menyatakan bahwa semakin bertambahnya bobot hidup domba maka produksi karkas juga ikut meningkat.Bobot karkas domba juga dipengaruhi oleh umur ternak, dimana umur ternak yang dipakai hampir seragam. Hal ini sesuai dengan pernyataan Owen dan Norman (1977), yang menyatakan bahwa jika umur ternak bertambah, maka bobot tubuh ternak bertambah sehingga akan meningkatkan produksi bobot karkas.

Hasil analisis pemberian jerami dengan berbagai perlakuan (fisik, kimia, biologi dan kombinasi) dalam pakan domba memberikan pengaruh yang berbeda nyata $(\mathrm{P}>$ 0,05) terhadap bobot karkas. Hal ini dapat diasumsikan karena setiap perlakuan mengandung komposisi pakan yang berbeda sehingga pakan setiap perlakuan memberikan respon yang tidak sama kualitasnya terhadap produksi bobot karkas.

Hasil uji BNJ 5\% didapat hasil perlakuan P1 dan P4 memiliki notasi yang sama yang artinya memberikan potensi yang sama pada kedua perlakuan tersebut dan berbeda nyata terhadap perlakuan P2 dan perlakuan P3. Pada perlakuan P3 (dengan penambahan 
Aspergillus niger) meningkatkan bobot karkas, hal ini diasumsikan bahwa dengan pengolahan jerami secara biologis dapat meningkatkan bobot karkas. Menurut Hardjo et al (1989) bahwa Aspergillus niger menghasilkan enzim ekstraselluler yang sangat baik untuk proses fermentasi.Dibandingkan dengan penelitian lainya,yaitu Haryanto (1992) bahwa bobot karkasnya yang menggunakan jerami padi berkisar antara $5-7 \mathrm{~kg}$,jadi bobot karkas penelitian saya ini adalah nyata negatif,karena tidak menunjukkan perbeaan yang nyata dari penelitian sebelumnya.

\section{Persentase Karkas}

Rataan persentase karkas yang tertinggi terdapat pada perlakuan P3 yaitu $32.63 \%$ dan rataan persentase yang terendah terdapat pada perlakuan P2 31.74\%. Rataan persentase karkas dipengaruhi oleh rataan bobot karkas, rataan bobot karkas tertinggi terdapat pada perlakuan P3 sebesar 3,99 kg dengan rataan persentase karkas terendah pada perlakuan P2 yaitu $3.65 \mathrm{~kg}$. Dari Tabel 3 diperoleh tampak bahwa persentase karkas yang diperoleh masih dari pernyataan Lawrie (1995), yang mengemukakan bahwa persentase domba yang gemuk sekitar $45-55 \%$.

Peningkatan persentase karkas juga sejalan dengan pertambahan bobot hidup domba. Hal ini sesuai dengan pendapat Davendra (1997) yang menyatakan bahwa karkas merupakan faktor yang penting untuk menilai produksi ternak pedaging, karena sangat erat hubungannya dengan bobot hidup semakin bertambah bobot hidup maka produksi karkas juga akan meningkat.

Pemberian jerami dengan berbagai perlakuan (fisik, kimia, biologi dan kombinasi) dalam pakan domba memberikan pengaruh yang tidak berbeda nyata $(\mathrm{P}>0,05)$ terhadap persentase karkas,ini didasarkan kandungan nutrisi pada jerami padi rendah dan mengakibatkan konversi pakan dari ternak kurang baik.

\section{Persentase Bobot Lemak Ginjal Domba}

Rataan persentase bobot lemak ginjal domba yang tertinggi terdapat pada perlakuan P3 yaitu 2,45 dan rataan persentase yang terendah terdapat pada perlakuan P1 yaitu sebesar 2,15. Tabel 3 pada analisis ragam menunjukkan pemberian jerami dengan berbagai perlakuan (fisik, kimia, biologi dan kombinasi) dalam pakan domba memberikan pengaruh yang tidak berbeda nyata $(\mathrm{P}>0,05)$ terhadap persentase bobot 
lemak ginjal domba. Menurut Berg dan Butterfield (1976), menyatakan bahwa jumlah lemak dalam tubuh adalah paling beragam dan sangat tergantung pada jumlah pakan dan ragam pakan yang dikonsumsi.

\section{Persentase Bobot Lemak Jantung Domba}

Rataan persentase yang tertinggi terdapat pada perlakuan P2 sebesar 2.30 dan terendah terdapat pada perlakuan P1, P2 dan P3 sebesar 2.25. Tabel 3 pada analisis ragam menunjukkan pemberian jerami dengan berbagai perlakuan (fisik, kimia, biologi dan kombinasi) dalam pakan domba memberikan pengaruh yang tidak berbeda nyata $(\mathrm{P}>0,05)$ terhadap persentase bobot lemak jantung domba,ini didasarkan adanya hubungan antara perlemakan dengan pertumbuhan bobot badan,pertumbuhan tidak nyata lemaknya tidak nyata,biasanya ternak yang kurus biasanya lemaknya juga sedikit.

\section{Persentase Bobot Lemak Pelvis Domba}

Rataan persentase yang tertinggi terdapat pada perlakuan P1 (jerami padi yang diolah secara fisik + konsentrat) sebesar 2.20 dan terendah terdapat pada perlakuan P2 (jerami padi yang diolah dengan kimia/ $\mathrm{NaOH}+$ konsentrat) dan P3 (jerami padi yang diolah secara biologis sebesar 2.10. Hasil analisis ragam, menunjukkan dalam pakan domba memberikan pengaruh yang tidak berbeda nyata $(\mathrm{P}>0,05)$ terhadap persentase bobot lemak pelvis domba,ini didasarkan adanya hungan lemak jantung dan pelvis,yang tidak beda jauh, jika lemak jantung tidak nyata maka lemak pelvis tidak nyata. Bahwa bobot lemak yang terdapat disekitar ginjal, pelvis dan jantung mempunyai pengaruh terhadap mutu karkas,karena dengan meningkatnya lemak tersebut akan mengakibatkan berkurangnya hasil pada potongan komersial karkas (Minish dan Fox, 1976).

\section{KESIMPULAN}

Keberadaan jerami padi yang diolah dengan berbagai perlakuan (fisik, kimia, biologi dan kombinasi) memberikan pengaruh yang berbeda terhadap bobot karkas, terutama pada perlakuan yang menggunakan Aspergilus niger, sedangkan perlakuan lainnya memberikan pengaruh yang sama terhadap persentase karkas, lemak ginjal, lemak jantung dan lemak pelvis pada domba. 


\section{DAFTAR PUSTAKA}

Arafah,2005. Pengelolaan jerami sebagai pupuk organik pada tanaman padi sawah.BPTP Sulawesi selatan.

Berg, R. T. dan Butterfield. R. M., 1976. New Conceps of Cattle Growth. Sydney University Press, Sydney.

Badan Pusat Statistik Sumatera Utara, 2002. Statistika Indonesia. Biro Pusat Statistik Indonesia. Jakarta.

Badan Pusat Statistik Sumatera Utara, 2004. Statistika Indonesia. Biro Pusat Statistik Indonesia. Jakarta.

Davendra, C. dan M. Burns, 1997. Produksi Kambing di Daerah Tropis. Institut Teknologi Bandung dan Universitas Udayana Bali.

Hardjo, S., N. S. Indrasti, B. Tajuddin., 1989. Bio-konversi Pemanfaatan Limbah Industri Pertanian. Pusat Antar Universitas Pangan dan Gizi, Institut Pertanian Bogor.

Jalaluddin, R,S. 2005. Pembuatan Jerami Padi Dengan Menggunakan Natrium Hidroksida. Universitas Malikusale Loksemawe,Aceh.

Lawrie, F. A. 1995. Ilmu Daging. Terjemahan oleh Aminuddin Parakkasi. Edisi Kelima. Indonesia University Press, Jakarta.

Minish, G.L and D.G Fox. 1976. Beef Production and Management. Preston. Pub. Co. Inc. Reston virgina.

Owen, J, B. 1979. Complent diets for catlle and sheep.farming press Ltd., Suffolk, England.

Parakkasi ,A. 1995. Ilmu Makanan dan Ternak Ruminan.UI-Press,Jakarta

Widayati ,E dan Widalestari. Y. 1996. Limbah Untuk Pakan Ternak. Trubus Agrisorana,Surabaya. 